\title{
Perencanaan Tempat Pengolahan Sampah Reduce, Reuse, Recycle Menggunakan Black Soldier Fly di Desa Karyamulya Kabupaten Ciamis
}

\author{
Melly Mellyanawaty ${ }^{1}$, Hendrik Iskandar ${ }^{2}$, Estin Nofiyanti $^{3}$, Nurcholis Salman $^{4}$ \\ 1,2,3,4 Teknik Lingkungan Universitas Muhammadiyah Tasikmalaya \\ Jl. Tamansari Km. 2,5 Mulyasari, Kec. Tamansari, Tasikmalaya, Jawa Barat 46196
}

*Koresponden email: melly@umtas.ac.id

Diterima: 8 Februari 2021

Disetujui: 5 Maret 2021

\begin{abstract}
Solid waste known as garbage still becomes one of the most concerning issues in Indonesia. It increases every year; however, the landfill was not expanded. The accumulation of garbage could give a negative impact on the environment and health. Due to this reason, there is an alternative suggested to reduce the garbage and its sources. The initiative called 'Bank sampah', itis a garbage treatment system which is managed by the community. In addition, the Reduce, Reuse, Recycle (3R) laystall was built to carry out some 'Bank Sampah'. This study conducted a preliminary design of 3R laystall at Desa Karyamulya Kecamatan Cisaga Kabupaten Ciamis. The design of the 3R laystall using black soldier fly method to decompose organic materials is employed in this research. The quantity and the density of the garbage were required to determine the design of the lay stall. Stratified random sampling was conducted for 8 days. Desa Karyamulya generates 2.361 liters/person/day or $0.236 \mathrm{~kg} /$ person/day. According to a population projection for the next 10 years, the estimation of garbage composition consists of food waste (52.15\%); plastic (23.58\%); paper (9.23\%); fabric (0.45\%); wood/leaf (6.38\%); diapers (2.85\%); metal $(0.94 \%)$; rubber/leather (2.19\%); glass $(0.17 \%)$; and styrofoam $(2.04 \%)$. From the quantity and composition of the garbage, it requires approximately $94 \mathrm{~m} 2$ of the area and an estimated funds needed as Rp. 483.908.600.
\end{abstract}

Keywords: black soldier fly, laystall, reduce, reuse, recycle, waste bank

\begin{abstract}
Abstrak
Limbah padat atau disebut juga sampah masih menjadi masalah besar yang dihadapi Indonesia hingga saat ini. Jumlah sampah meningkat setiap tahunnya, namun tidak diimbangi penambahan luas area tempat pengolahan akhir. Penumpukan sampah dapat berdampak negatif bagi lingkungan dan kesehatan. Pengurangan sampah dari sumbernya dapat menjadi alternatif untuk mengatasi penumpukan sampah. Bank sampah adalah sistem pengolahan sampah yang dikelola oleh masyarakat. Dengan dibangunnya TPS reduce, reuse, recycle (3R) dapat sekaligus dipadukan dengan sistem bank sampah. Studi ini dilakukan untuk merencanakan desain awal TPS 3R di Desa Karyamulya Kecamatan Cisaga Kabupaten Ciamis. Penelitian ini merancang TPS 3R dengan menggunakan metode black soldier fly untuk menguraikan bahan organik. Timbulan dan densitas sampah diperlukan untuk menentukan desain TPS 3R dengan metode stratified random sampling yang dilakukan selama 8 hari. Desa Karyamulya menghasilkan 2.361 liter/orang/hari atau 0,236 kg/orang/hari. Dengan proyeksi jumlah penduduk 10 tahun ke depan, estimasi komposisi sampah terdiri dari sisa makanan $(52,15 \%)$; plastik $(23,58 \%)$; kertas $(9,23 \%)$; kain $(0,45 \%)$; kayu/daun $(6,38 \%)$; popok (2,85\%); logam (0,94\%); karet/kulit (2,19\%); kaca $(0,17 \%)$; dan Styrofoam $(2,04 \%)$. Dari jumlah dan komposisi sampah tersebut, diperlukan luas areal untuk TPS sekitar $94 \mathrm{~m}^{2}$ dengan perkiraan kebutuhan dana sebesar Rp. 483.908.600.
\end{abstract}

Kata Kunci: bank sampah, black soldier fly, daur ulang, 3R, TPS

\section{Pendahuluan}

Sampah masih terus menjadi permasalahan besar di Indonesia dan belum dapat terselesaikan. Meningkatnya jumlah timbulan sampah dipengaruhi oleh jumlah penduduk, laju pembangunan dan tingkat sosial ekonomi masyarakat mengalami peningkatan setiap tahunnya [1] [2]. Masalah yang kemudian muncul adalah peningkatan jumlah sampah tidak diimbangi dengan perluasan lahan tempat pembuangan sampah. Hal 
ini menyebabkan penumpukan sampah yang semakin lama semakin menggunung. Pada paradigma lama pengelolaan sampah hanya terpaku pada kumpul, angkut dan buang tanpa adanya pemilahan dan pemanfaatan sampah yang masih memiliki nilai baik secara ekonomi atau kegunaan. Pengelolaan sampah dengan paradigma lama dapat membuat umur TPA lebih singkat sehingga pemerintah harus menyediakan TPA baru sebagai pengganti TPA yang lama.

Komposisi sampah organik umumnya memiliki jumlah yang lebih besar dari sampah anorganik [3] [4]. Pada studi ini, sampah organik diolah menggunakan metode black soldier fly (BSF). Penggunaan larva BSF dalam peruraian material organik sangat menjanjikan. Larva BSF mengadung sumber protein yang dapat digunakan sebagai pakan hewan [5], sehingga bisa dijadikan sebagai alternatif pakan menggantikan pengganti pakan pellet atau sejenisnya [6] [7]. Larva BSF ini dapat menjadi pengurai sampah organik yang biasa dihasilkan rumah tangga [8] [9].

Upaya mereduksi sampah dari sumbernya merupakan salah satu alternatif pengurangan jumlah sampah di TPA. Keberadaan bank sampah sebagai tempat pengumpulan sampah kering yang mengadopsi manajemen bank pada dasarnya dibentuk untuk membangun kepedulian masyarakat terhadap sampah. Perancangan Tempat Pengolahan Sampah Reduce, Reuse, Recycle atau yang dikenal dengan TPS 3R diharapkan dapat mengurangi dampak penumpukan sampah [10], [11]. Desa Karyamulya merupakan salah satu daerah yang belum memiliki TPS 3R. Desa Karyamulya terletak di Kecamatan Cisaga Kabupaten Ciamis memiliki penduduk sebanyak 3.744 jiwa, yaitu 1.847 jiwa penduduk laki-laki dan 1.897 jiwa penduduk perempuan [12]. Untuk mengatasi beberapa permasalahan yang ditimbulkan dari sampah, maka Desa Karyamulya memerlukan adanya pengelolaan sampah melalui TPS 3R. Studi ini dilakukan untuk merencanakan TPS 3R dengan BSF sebagai pengolah sampah organik di Desa Karyamulya, Ciamis.

\section{Metode Penelitian Data Primer}

Data timbulan, densitas dan komposisi sampah di Desa Karyamulya dikumpulkan sebagai data primer. Tahapan untuk mengetahui data timbulan, densitas dan komposisi sampah yaitu dengan metode stratified random sampling. Metode stratified random sampling mengacu pada pendapatan penduduk setempat, dengan asumsi bahwa kualitas dan kuantitas sampah dipengaruhi oleh tingkat kehidupan masyarakat [13]. Pengambilan sampel dilakukan selama 8 hari secara berturut-turut SNI-19-3964-1994. Sebelum dilakukan pengambilan sampel, ditentukan terlebih dahulu jumlah jiwa/Kepala Keluarga (KK) serta jumlah sampel rumah permanen, semi permanen dan non permanen. Penentuan jumlah sampel sampah yang diambil merujuk pada Persamaan 1 dan Persamaan 2 [14].

Bila penduduk $\leq 10^{6}$ jiwa

$P=C d \cdot \sqrt{P S}$

Keterangan:

$P s=$ jumlah penduduk bila $\leq 10^{6}$ jiwa

$C d=$ Koefisien

a. Bila penduduk $>10^{6}$ jiwa

$$
\mathrm{P}=\mathrm{Cd} . \mathrm{Cj} \cdot \sqrt{\mathrm{Ps}}
$$

$C j=\frac{\sum \text { Penduduk }}{10^{6}}$

$C d=1$ Bila kepadatan penduduk normal

$C d<1$ Bila kepadatan penduduk jarang

$C d>1$ Bila Kepadatan penduduk padat

Tahapan pengambilan sampel diawali dengan pembagian kantong plastik sehari sebelum pelaksanaan pengambilan sampel pada rumah yang telah dipilih secara random. Masing-masing sampel dimasukkan ke dalam kotak 40 L (Gambar 1), kemudian dihentakkan 3 kali setelah diangkat $20 \mathrm{~cm}$. Volume sampah diukur 
dan dicatat, selanjutnya komposisi sampah ditentukan dengan cara memilah sampah berdasarkan komponen sampah (sisa makanan, plastik, kertas, daun, kayu, karet, kain, kaca, logam, dan lain-lain). Masing-masing komponen ditimbang dan dihitung persentase komposisi sampah masing-masing.

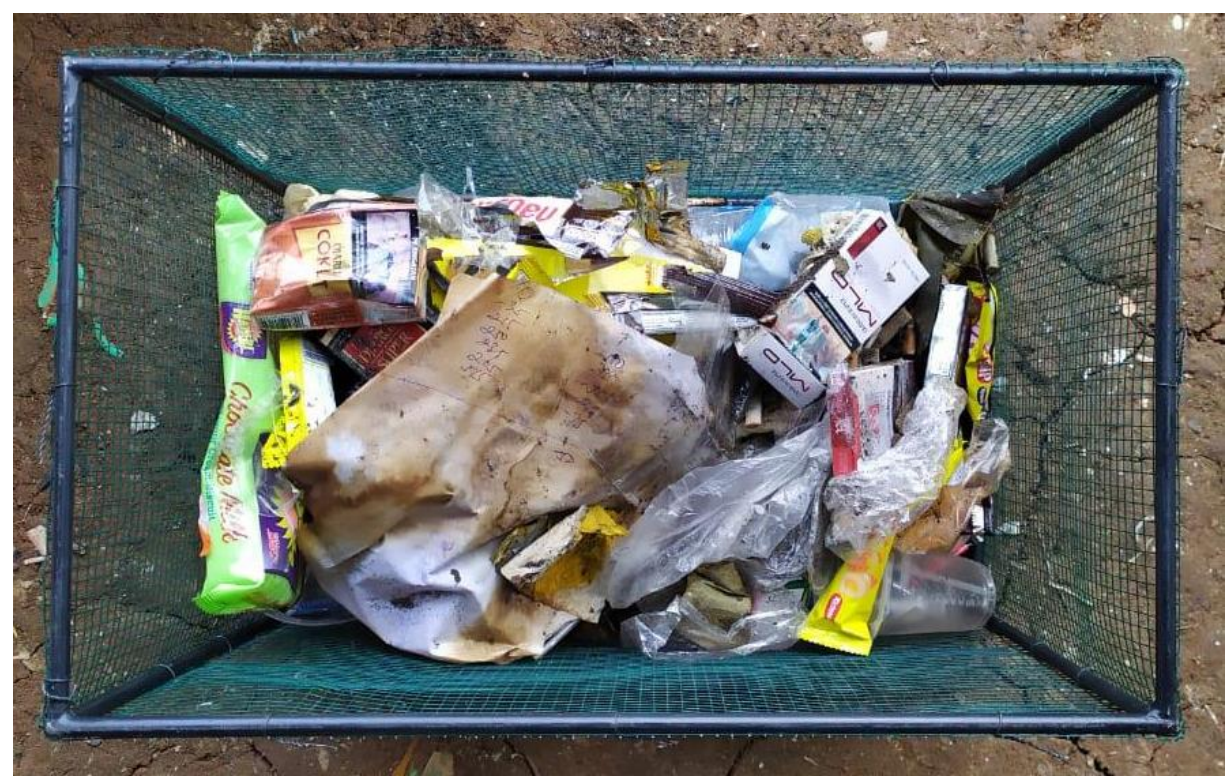

Gambar 1. Kotak untuk mengukur volume sampah Sumber: Hasil penelitian (2020)

\subsection{Data Sekunder}

Data sekunder yang dikumpulkan yaitu profil Desa Karyamulya sebagai gambaran umum Desa Karyamulya, data kependudukan Desa Karyamulya selama 5 tahun terakhir, Standar Timbulan Sampah (SNI 19-3964-1995), dan laju timbulan dan komposisi sampah Desa Karyamulya dan digunakan sebagai proyeksi laju timbulan sampah selama minimal 10 tahun mendatang. Gambar 2 menunjukkan kondisi tempat pembuangan sampah di Desa Karyamulya saat ini dan Gambar 3 menunjukkan peta lokasi penelitian dan titik TPS 3R.

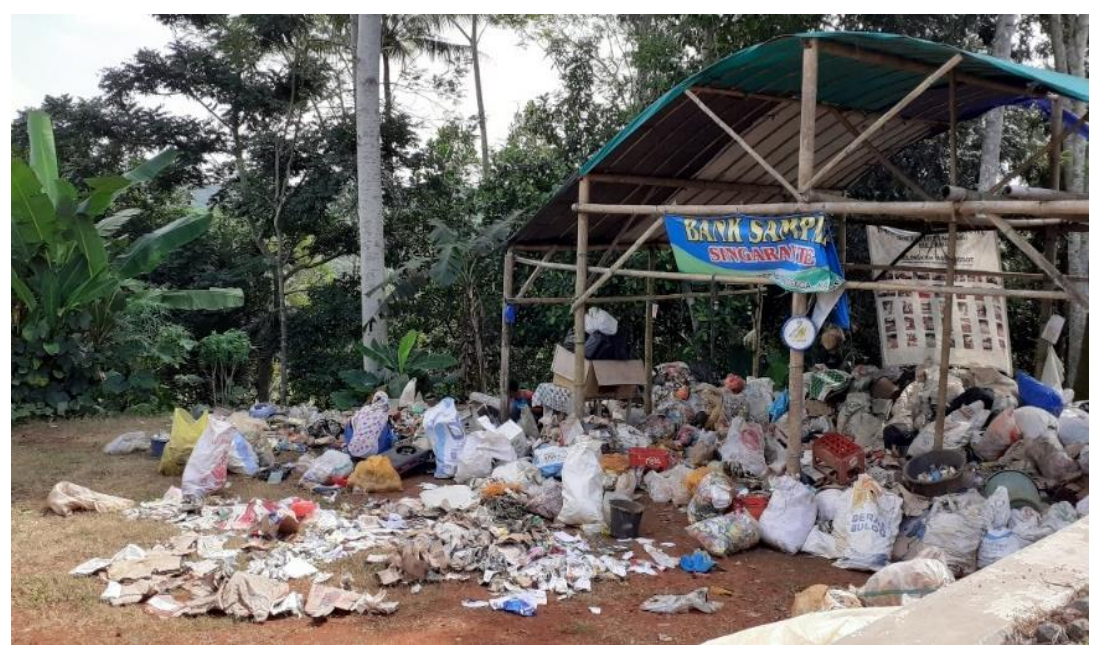

Gambar 2. Kondisi TPS Desa Karyamulya Sumber: Hasil penelitian (2020) 


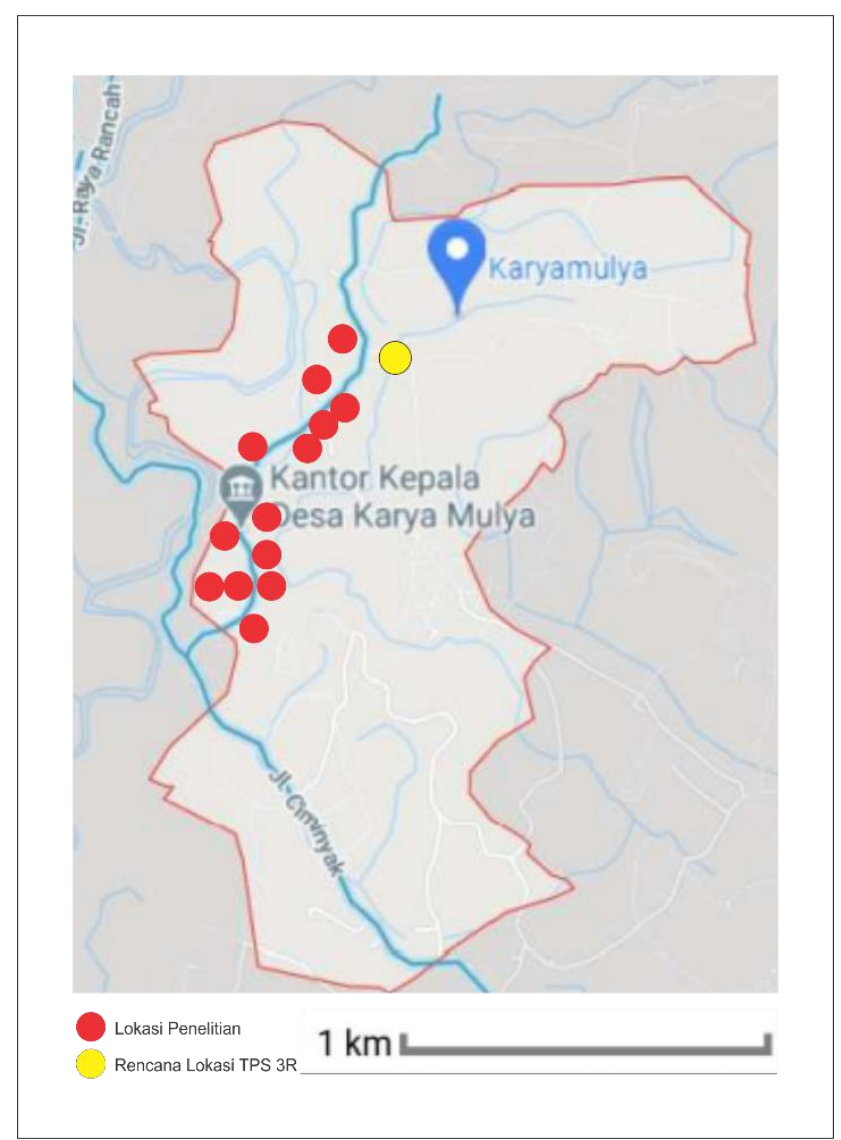

Gambar 3. Lokasi penelitian dan titik rencana TPS 3R Sumber: Hasil penelitian (2020)

\subsection{Pengolahan dan Analisis Data}

Data primer dan data sekunder dianalisis selama proses perencanaan. Komponen yang dihitung di antaranya:

a. Timbulan Sampah

Timbulan sampah dihitung menggunakan Persamaan 4.

Timbulan Sampah $=\frac{V 1+V 2+V 3 \ldots \ldots . . . V n}{n}$ liter/orang/hari

dengan,

$n=$ jumlah sumber sampah

$v=$ volume sampah dari sumber

Setelah diketahui rata-rata timbulan sampah dari sumber sampah, selanjutnya dikalikan dengan proyeksi penduduk Desa Karyamulya.

b. Komposisi Sampah

Komposisi sampah dinyatakan dalam (\%). Masing-masing komponen sampah ditimbang, persentase komposisi sampah dapat diketahui melalui Persamaan 5.

Komposisi sampah $(\%)=\frac{\text { Berat komponen sampah }}{\text { Berat total sampah }} \times 100 \%$

c. Densitas Sampah

Persamaan 2.6 digunakan dalam penentuan densitas sampah.

Densitas Sampah $=\frac{\text { Berat sampah }(\mathrm{kg})}{\text { Volume } \operatorname{sampah}\left(\mathrm{m}^{3}\right)}$ 


\section{Hasil dan Pembahasan}

Penentuan jumlah sampel timbulan sampah menggunakan metode stratified random sampling. Klasifikasi bangunan dianggap dapat mewakili tingkat ekonomi masyarakat. Klasifikasi jenis rumah Desa Karyamulya ditampilkan pada Tabel 1.

Tabel 1. Klasifikasi jenis rumah Desa Karyamulya

\begin{tabular}{cccc}
\hline \multicolumn{4}{c}{ Klasifikasi Jenis Rumah } \\
\hline Permanen & $\begin{array}{c}\text { Semi } \\
\text { Permanen }\end{array}$ & $\begin{array}{c}\text { Non } \\
\text { Permanen }\end{array}$ & Jumlah \\
& 253 & 101 & 1182 \\
828 & $21 \%$ & $9 \%$ & $100 \%$ \\
$70 \%$ & Sumber: Data Pemdes Karyamulya (2020)
\end{tabular}

Berdasarkan hasil perhitungan SNI 19-3964-1994 untuk mengetahui sampel jiwa, diperoleh sebanyak 60 jiwa atau 13 rumah dengan asumsi setiap rumah beranggotakan 5 orang. Pengambilan sampel dilakukan 8 hari berturut-turut mulai dari tanggal 2 Juni-9 Juni 2020. Jumlah sampel berdasarkan jenis bangunan dapat dilihat pada Tabel 2.

Tabel 2. Jumlah sampel berdasarkan jenis bangunan

\begin{tabular}{clcc}
\hline No & Klasifikasi Jenis Rumah & Persentase & Jumlah Rumah Sampel \\
\hline 1. & Permanen & $70 \%$ & 9 \\
2. & Semi Permanen & $21 \%$ & 3 \\
3. & Non Permanen & $9 \%$ & 1 \\
\hline \multicolumn{3}{c}{ Jumlah Sumber: Hasil penelitian (2020) }
\end{tabular}

Hasil pengukuran rata-rata timbulan sampah Desa Karyamulya yang dilakukan selama 8 hari disajikan pada Tabel 3 .

Tabel 3. Rata-rata timbulan sampah Desa Karyamulya

\begin{tabular}{cccc}
\hline No & Sampel & $\begin{array}{c}\text { Rata-rata Sampah } \\
\text { (L/hari) }\end{array}$ & $\begin{array}{c}\text { Rata-rata Sampah } \\
\text { (kg/hari) }\end{array}$ \\
\hline 1. & Sampel 1 & 14,182 & 1,613 \\
2. & Sampel 2 & 10,321 & 1,368 \\
3. & Sampel 3 & 22,869 & 2,238 \\
4. & Sampel 4 & 13,142 & 1,206 \\
5. & Sampel 5 & 10,841 & 0,950 \\
6. & Sampel 6 & 6,089 & 0,559 \\
7. & Sampel 7 & 12,029 & 0,595 \\
8. & Sampel 8 & 11,806 & 1,163 \\
9. & Sampel 9 & 10,395 & 1,181 \\
10. & Sampel 10 & 7,426 & 0,706 \\
11. & Sampel 11 & 4,099 & 0,429 \\
12. & Sampel 12 & 9,875 & 1,013 \\
13. & Sampel 13 & 8,613 & 1,013 \\
\hline \multicolumn{5}{c}{ Total Harian } & 141,685 & 14,032 \\
\hline \multicolumn{5}{c}{ Sumber: Hasil penelitian (2020) }
\end{tabular}

Dari volume dan berat sampah, data timbulan sampah per orang dari Desa Karyamulya dapat diketahui dengan membagi jumlah rata-rata volume dan berat sampah dengan jumlah sampel jiwa berturut-turut sebanyak 2,361 L/orang/hari dan 0,236 kg/orang/hari. Komposisi sampah yang diukur merupakan jenis sampah sehari-hari yang sering ditemui di masyarakat. Komposisi Sampah Desa Karyamulya berdasarkan persentase disajikan pada Gambar 4. Jenis sampah sisa makanan menempati komposisi urutan nomor satu dikarenakan sampah sisa makanan merupakan sampah yang paling banyak dihasilkan dari setiap rumah 
sampel, sedangkan plastik berada pada posisi kedua karena sebagian masyarakat masih menggunakan atau membeli produk dengan kemasan berbahan dasar plastik.

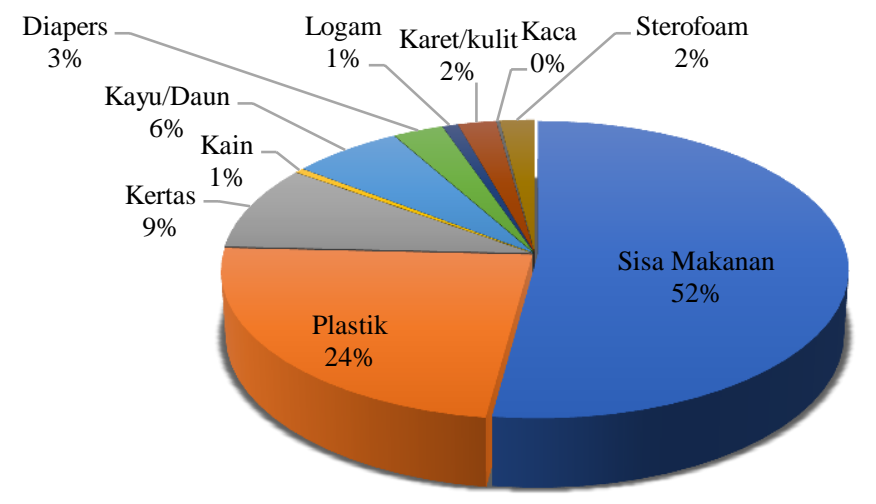

Jenis Sampah

- Sisa Makanan

- Plastik

Kertas

Kain

- Kayu/Daun

Diapers

- Logam

Karet/kulit

Kaca

- Sterofoam

Gambar 4. Grafik komposisi sampah Sumber: Hasil penelitian (2020)

Hasil perhitungan estimasi laju timbulan sampah Desa Karyamulya untuk 10 tahun ke depan dapat dilihat pada Tabel 4. Dari Tabel 4 di diketahui estimasi timbulan sampah Desa Karyamulya pada tahun 2030 sebesar $9,27 \mathrm{~m}^{3} /$ hari atau $926,5 \mathrm{~kg} / \mathrm{hari}$ atau 0,926 ton/hari.

Tabel 4. Estimasi laju timbulan sampah Desa Karyamulya

\begin{tabular}{cccccc}
\hline \multirow{2}{*}{ Tahun } & \multirow{2}{*}{ Jumlah Penduduk } & \multicolumn{4}{c}{ Timbulan Sampah } \\
\cline { 2 - 5 } & & $\mathrm{m}^{3} / \mathrm{hari}$ & $\mathrm{m}^{3}$ /orang/hari & $\mathrm{kg} / \mathrm{hari}$ & $\mathrm{kg} /$ orang/hari \\
\hline 2021 & 3.855 & 9,10 & 0,00236 & 909,8 & 0,2360 \\
2022 & 3.863 & 9,12 & 0,00237 & 911,7 & 0,2365 \\
2023 & 3.871 & 9,14 & 0,00237 & 913,6 & 0,2370 \\
2024 & 3.879 & 9,16 & 0,00238 & 915,4 & 0,2375 \\
2025 & 3.887 & 9,18 & 0,00238 & 917,3 & 0,2380 \\
2026 & 3.894 & 9,20 & 0,00239 & 919,0 & 0,2384 \\
2027 & 3.902 & 9,21 & 0,00239 & 920,9 & 0,2389 \\
2028 & 3.910 & 9,23 & 0,00240 & 922,8 & 0,2394 \\
2029 & 3.918 & 9,25 & 0,00240 & 924,6 & 0,2399 \\
\hline 2030 & 3.926 & 9,27 & 0,00240 & 926,5 & 0,2403 \\
\hline \multicolumn{5}{c}{ Sumber: Hasil penelitian $(2020)$} \\
\end{tabular}

Untuk merancang sebuah TPS 3R diperlukan data volume dan berat dari masing-masing komposisi sampah. Hasil perhitungan estimasi laju timbulan sampah Desa Karyamulya untuk 10 tahun ke depan seperti pada Tabel 5.

Tabel 5. Estimasi berat dan volume komposisi sampah Desa Karyamulya

\begin{tabular}{clccc}
\hline No & Jenis Sampah & Komposisi Sampah & Volume sampah $\left(\mathrm{m}^{3} /\right.$ hari $)$ & Berat Sampah $(\mathrm{kg} / \mathrm{hari})$ \\
\hline 1. & Sisa Makanan & $52,15 \%$ & 4,83 & 483,19 \\
2. & Plastik & $23,58 \%$ & 2,19 & 218,49 \\
3. & Kertas & $9,23 \%$ & 0,86 & 85,53 \\
4. & Kain & $0,45 \%$ & 0,04 & 4,19 \\
5. & Kayu/Daun & $6,38 \%$ & 0,59 & 59,11 \\
6. & Diapers & $2,85 \%$ & 0,26 & 26,45 \\
7. & Logam & $0,94 \%$ & 0,09 & 8,74 \\
\hline
\end{tabular}




\begin{tabular}{clccc}
\hline 8. & Karet/kulit & $2,19 \%$ & 0,20 & 20,31 \\
9. & Kaca & $0,17 \%$ & 0,02 & 1,55 \\
10. & Styrofoam & $2,04 \%$ & 0,19 & 18,94 \\
\hline & Jumlah & $100 \%$ & 9,27 & 926,50 \\
\hline
\end{tabular}

Sumber: Hasil penelitian (2020)

Perhitungan neraca massa sampah ditampilkan pada Tabel 6 yang dihitung dari data komposisi sampah dan faktor terhadap pemilahan dari beberapa jenis sampah. Dengan demikian total sampah yang dibuang ke TPA sebanyak 0,200 ton/hari sedangkan sampah yang didaur ulang dan tertahan di TPS 3R adalah $78,43 \%$ atau sebanyak 0,726 ton/hari.

Tabel 6. Neraca massa sampah

\begin{tabular}{|c|c|c|c|c|c|c|c|c|}
\hline \multirow{2}{*}{$\begin{array}{l}\text { Perlakuan } \\
\text { di TPS 3R }\end{array}$} & \multirow{2}{*}{$\begin{array}{l}\text { Jenis } \\
\text { Sampah }\end{array}$} & \multirow{2}{*}{$\begin{array}{c}\text { Rata-Rata } \\
\text { Komposisi } \\
\text { Sampah }\end{array}$} & \multirow{2}{*}{$\begin{array}{c}\text { Faktor } \\
\text { Terhadap } \\
\text { Pemilahan }\end{array}$} & \multirow{2}{*}{$\begin{array}{c}\text { Rata- } \\
\text { Rata } \\
\text { Komposi } \\
\text { si } \\
\text { Sampah } \\
\end{array}$} & \multicolumn{2}{|c|}{$\begin{array}{c}\text { Rata-Rata } \\
\text { Timbulan Sampah }\end{array}$} & \multicolumn{2}{|c|}{ Timbulan Sampah } \\
\hline & & & & & ton/hari & $\mathrm{m}^{3} /$ hari & ton/hari & $\mathrm{m}^{3} / \mathrm{hari}$ \\
\hline \multirow[t]{3}{*}{$\begin{array}{l}\text { Diolah di } \\
\text { TPS 3R }\end{array}$} & $\begin{array}{l}\text { Sisa } \\
\text { Makanan }\end{array}$ & $52,15 \%$ & - & $52,15 \%$ & \multirow{19}{*}{0,92} & \multirow{19}{*}{9,27} & 0,483 & 4,83 \\
\hline & Kayu/Daun & $6,38 \%$ & - & $6,38 \%$ & & & 0,059 & 0,59 \\
\hline & Jumlah & $58,53 \%$ & - & $58,53 \%$ & & & 0,542 & 5,43 \\
\hline \multirow{6}{*}{$\begin{array}{l}\text { Diolah di } \\
\text { TPS 3R }\end{array}$} & Plastik & $23,58 \%$ & $50 \%$ & $11,79 \%$ & & & 0,109 & 1,09 \\
\hline & Kertas & $9,23 \%$ & $50 \%$ & $4,62 \%$ & & & 0,043 & 0,43 \\
\hline & Kain & $0,45 \%$ & - & $0,45 \%$ & & & 0,004 & 0,04 \\
\hline & Logam & $0,94 \%$ & $90 \%$ & $0,85 \%$ & & & 0,008 & 0,08 \\
\hline & Karet/kulit & $2,19 \%$ & - & $2,19 \%$ & & & 0,020 & 0,20 \\
\hline & Jumlah & $36,40 \%$ & - & $19,90 \%$ & & & 0,184 & 1,84 \\
\hline \multirow[t]{3}{*}{ Ke TPA } & $\begin{array}{l}\text { Diapers } \\
\text { (Popok bayi } \\
\text { sekali pakai) }\end{array}$ & $2,85 \%$ & - & $2,85 \%$ & & & 0,026 & 0,26 \\
\hline & Styrofoam & $2,04 \%$ & - & $2,04 \%$ & & & 0,019 & 0,19 \\
\hline & Jumlah & $4,90 \%$ & - & $4,90 \%$ & & & 0,045 & 0,45 \\
\hline Diangkut & Kaca & $0,17 \%$ & $65 \%$ & $0,11 \%$ & & & 0,001 & 0,01 \\
\hline Ke TPA & Jumlah & $0,17 \%$ & - & $0,11 \%$ & & & 0,001 & 0,01 \\
\hline Diangkut & Plastik & $23,58 \%$ & $50 \%$ & $11,79 \%$ & & & 0,109 & 1,09 \\
\hline Ke TPA & Kertas & $9,23 \%$ & $50 \%$ & $4,62 \%$ & & & 0,043 & 0,43 \\
\hline (Residu & Logam & $0,94 \%$ & $10 \%$ & $0,09 \%$ & & & 0,001 & 0,01 \\
\hline \multirow[t]{2}{*}{ Pemilahan) } & Kaca & $0,17 \%$ & $35 \%$ & $0,06 \%$ & & & 0,001 & 0,01 \\
\hline & Jumlah & $0,17 \%$ & - & $16,56 \%$ & & & 0,153 & 1,54 \\
\hline
\end{tabular}

Sumber: Hasil penelitian (2020)

Desa Karyamulya telah memiliki unit pengelolaan sampah berbasis pemberdayaan masyarakat yaitu Bank Sampah Singarante. Perencanaan pengelolaan sampah melalui TPS 3R di Desa Karyamulya diintegrasikan dengan Bank Sampah Singarante, sesuai dengan Peraturan Menteri Pekerjaan Umum Republik Indonesia Nomor 03/PRT/M/2013 tentang Penyelenggaraan Prasarana dan Sarana Persampahan dalam Penanganan Sampah Rumah Tangga dan Sampah Sejenis Sampah Rumah Tangga [16]. Berdasar peraturan tersebut memperbolehkan TPS 3R diintegrasikan dengan Bank Sampah.

Nasabah atau masyarakat yang akan menabung hendak membawa sampah yang telah terpilah dari rumah guna ditabung di bank sampah. Dengan mengintegrasikan TPS 3R dengan bank sampah maka proses pengumpulan sampah dapat dilakukan secara mandiri oleh masyarakat, sehingga dapat mengurangi alur pekerjaan TPS 3R dalam pengumpulan sampah. Pada Gambar 5 dapat dilihat alur pengelolaan sampah di TPS 3R Desa Karyamulya. 


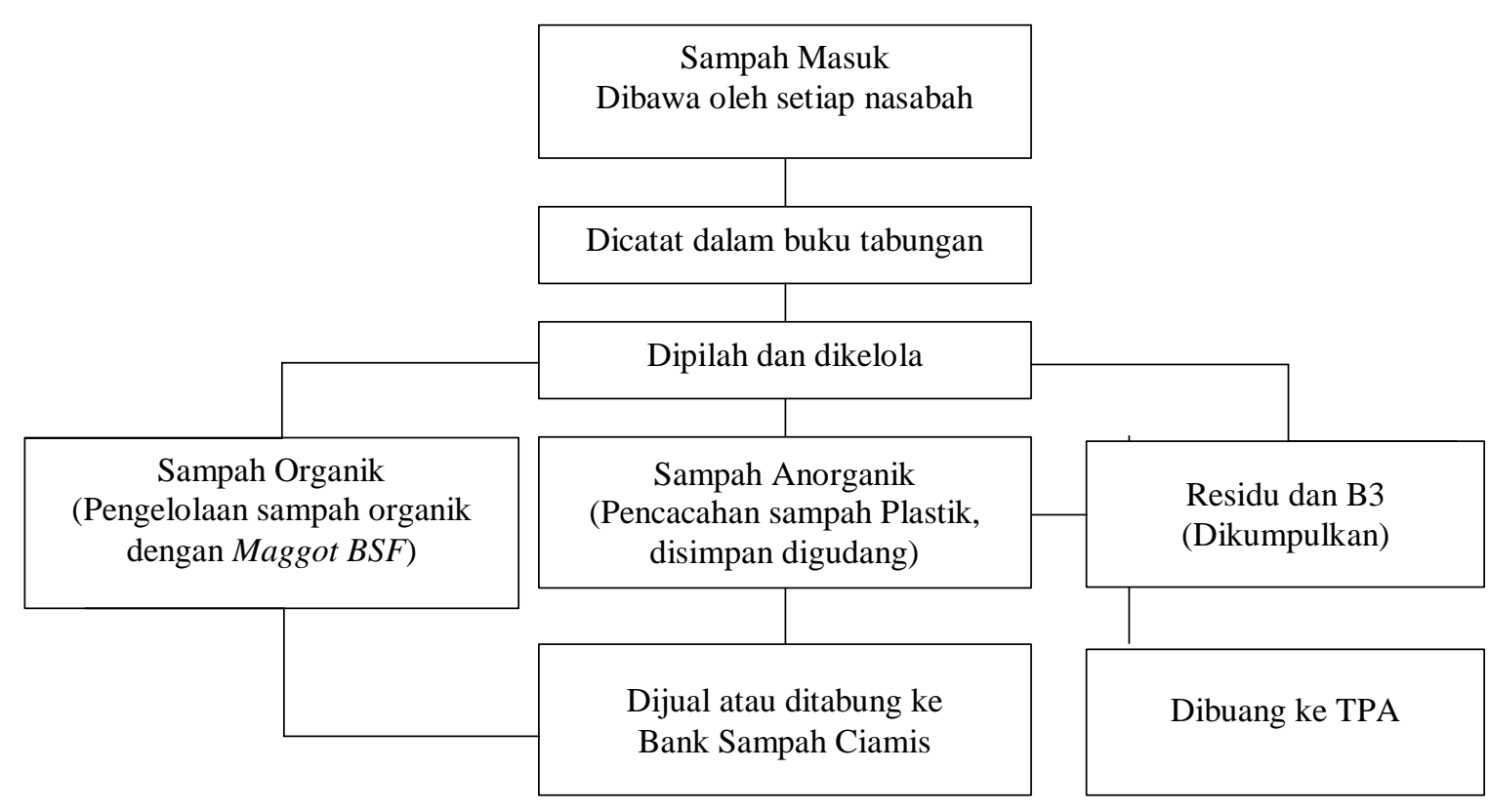

Gambar 5. Alur pengelolaan sampah di TPS 3R Desa Karyamulya Sumber: Hasil penelitian (2020)

Pengolahan sampah organik di TPS 3R menggunakan metode Maggot Black Soldier Fly (BSF). Estimasi timbulan sampah organik Desa Karyamulya sebesar $542 \mathrm{~kg} /$ hari. Larva BSF dapat mengurai sampah organik sebanyak $15 \mathrm{~kg} / \mathrm{m}^{2} /$ hari [17] dengan menggunakan biopod atau tempat budidaya yang memiliki dimensi $3 \mathrm{mx} 1 \mathrm{~m}$ atau $3 \mathrm{~m}^{2}$. Kebutuhan biopod TPS 3R Desa Karyamulya sebanyak 12 buah dan kebutuhan area biopod sebesar $24 \mathrm{~m}^{2}\left(6 \mathrm{~m}^{2} /\right.$ rangkaian biopod). Kebutuhan kandang BSF dewasa $1 \mathrm{~m}^{2}$ dan total kebutuhan area pengolahan sampah organik adalah $25 \mathrm{~m}^{2}$.

Desain TPS 3R Desa Karyamulya dibuat berdasarkan hasil perhitungan kebutuhan luas lahan TPS 3R Desa Desa Karyamulya. Total luas minimum yang dibutuhkan untuk perencanaan TPS 3R Desa Karyamulya yaitu $94 \mathrm{~m}^{2}$, dengan kebutuhan luasan masing-masing komponen disajikan pada Tabel 6. Dari hasil perhitungan bangunan yang direncanakan, diketahui anggaran biaya yang diperlukan untuk membangun TPS 3R Desa Karyamulya adalah sebesar Rp. 483.908.600,00.

Tabel 6. Kebutuhan luas lahan TPS 3R Desa Karyamulya

\begin{tabular}{clc}
\hline No & \multicolumn{1}{c}{ Komponen TPS 3R } & Luas Area $\left(\mathrm{m}^{2}\right)$ \\
\hline 1. & Kantor TPS 3R & 6 \\
2. & Galeri/ Ruang Serbaguna & 20 \\
3. & Area Penimbangan \& Pemilahan & 9 \\
4. & Area Pencacahan & 12 \\
5. & Area Pengelolaan Sampah Organik & 25 \\
6. & Area Penyimpanan Sementara & 13 \\
7. & Musala & 6 \\
8. & Toilet & 3 \\
\hline \multicolumn{2}{c}{ Total } \\
\hline \multicolumn{2}{c}{ Sumber: Hasil penelitian $(2020)$} \\
\end{tabular}

\section{Kesimpulan}

Proyeksi jumlah penduduk Desa Karyamulya pada tahun 2030 ialah sebanyak 3.926 jiwa. Jumlah timbulan sampah Desa Karyamulya 10 tahun ke depan sebesar 9,346 $\mathrm{m}^{3} / \mathrm{hari}$ atau 934,08 $\mathrm{kg} / \mathrm{hari}$. Total luas minimum yang diperlukan untuk pembangunan TPS 3R Desa Karyamulya adalah $94 \mathrm{~m}^{2}$ dengan perkiraan biaya yang diperlukan sebesar Rp. 483.908.600,00. 


\section{Referensi}

[1] M. A. S. Hasyim, "Perencanaan Tempat Penampungan Sementara Sampah Di Kecamatan Kota Sumenep," Surabaya: Fakultas Teknik Sipil dan Perencanaan Institut Teknologi Sepuluh November, 2014.

[2] "Bertambahnya Sampah Akibat Pertambahan Penduduk di Surabaya - Kompasiana.com." [Online]. Available: https://www.kompasiana.com/nicoirjaya92/550b637e813311f813b1e5d7/bertambahnyasampah-akibat-pertambahan-penduduk-di-surabaya. [Accessed: 08-Feb-2021].

[3] R. Windraswara, D. A. B. Prihastuti, "Analisis Potensi Reduksi Sampah Rumah Tangga Untuk Peningkatan Kualitas Kesehatan Lingkungan," Unnes J. Public Heal., vol. 6, no. 2, p. 123, 2017.

[4] F. Zahra, T. Padmi Damanhuri, "Kajian Komposisi, Karakteristik, Dan Potensi Daur Ulang Sampah Di TPA Cipayung, Depok Study of Composition, Characteristic, and Recycling Potential of Waste At Cipayung Final Disposal Site,Depok," J. Tek. Lingkung., vol. 17, no. April, p. 59, 2011.

[5] Y.-S. Wang, M. Shelomi, "Review of Black Soldier Fly (Hermetia illucens) as Animal Feed and Human Food," Foods, vol. 6, no. 10, p. 91, Oct. 2017.

[6] B. Dortmans, S. Diener, B. Verstappen, C. Zurbrugg, Proses Pengolahan Sampah Organik dengan Black Soldier Fly (BSF): Panduan Langkah-Langkah Lengkap, 2017.

[7] C. H. Lalander, J. Fidjeland, S. Diener, S. Eriksson, B. Vinnerås, "High waste-to-biomass conversion and efficient Salmonella spp. reduction using black soldier fly for waste recycling," Agron. Sustain. Dev., vol. 35, no. 1, pp. 261-271, Jan. 2014.

[8] F. F. Hidayah, N. R. Destya, B. Candra, "Pemanfaatan Larva Black Soldier Fly ( Hermatia illucens ) sebagai Penanggulangan Sampah Organik melalui Budidaya Magot (Utilization of Black Soldier Fly (Hermetia illucens) Larvae as Organic Waste Management through Maggot Cultivation )," J. Pus. Inov. Masy., vol. 2, no. 4, pp. 530-534, 2020.

[9] G. D. P. da Silva, T. Hesselberg, "A Review of the Use of Black Soldier Fly Larvae, Hermetia illucens (Diptera: Stratiomyidae), to Compost Organic Waste in Tropical Regions," Neotropical Entomology, vol. 49, no. 2. Springer, pp. 151-162, 01-Apr-2020.

[10] Kementrian PU, "Petunjuk Teknis TPS 3R," 2016.

[11] S. Haryanti, E. Gravitianai, W. Mahendra, "Studi Penerapan Bank Sampah dalam Upaya Pengelolaan Lingkungan Hidup di Kota Yogyakarta," Bioeksperimen, vol. 6, no. 1, 2020.

[12] BPS, "Kecamatan Cisaga Dalam Angka 2019,” 2019.

[13] R. Anisa, D. M. Hartono, K. Muhaemin, "Desain Tempat Pengolahan Sampah Reduce, Reuse, Recycle (TPS 3R) Terintegrasi Bank Sampah Pada Kawasan Perkampungan (Studi Kasus : Kampung Maruga , Tangerang Selatan)," pp. 1-20, 2014.

[14] E. Damanhuri, T. Padmi, "Pengelolaan Sampah Terpadu," II., E. Warsidi, Ed. Bandung: Institut Teknologi Bandung, 2019.

[15] SNI19-3964-1994, "Metode pengambilan dan pengukuran contoh timbulan dan komposisi sampah perkotaan," 1994.

[16] P. M. P. U. R. INDONESIA, "Penyelenggaraan Prasarana Dan Sarana Persampahan Dalam Penanganan Sampah Rumah Tangga Dan Sampah Sejenis Sampah Rumah Tangga," [Online]. Available: http://ciptakarya.pu.go.id/plp/upload/peraturan/Permen_PU_No_3_Tahun_2013_-

_Penyelenggaraan_PS_Persampahan.pdf. [Accessed: 08-Feb-2021].

[17] H. H. Park, "Black Soldier Fly Larvae Manual," Student Showc., vol. 14, pp. 1-13, 2016. 